\title{
LOGISTICS BONDED CENTER AS NEW CUSTOMS FACILITY BREAKTHROUGH FOR REDUCING LOGISTICS TIME AND COST
}

\author{
Raden Didiet Rachmat Hidayat ${ }^{1}$, Mohammad Iqbal Firdaus ${ }^{2}$, Lis \\ Lesmini $^{3}$, Harry Purwoko 4 \\ 1. STMT Trisakti, 2. STMT Trisakti, 3. STMT Trisakti, 4. STMT Trisakti \\ $\triangle$ corresponding author:: didiet.hidayat@yahoo.com
}

\begin{abstract}
The Bonded Logistics Center (PLB) as the Government's Economic Policy Package issued in September 2015. This clarified by Regulation of the Minister of Finance No. 272 Year 2015 on Bonded Logistics Center (PLB) plus the Regulation of the Director General of Customs and Excise No. 1 of 2016, Regulation of the Director General of Customs and Excise No. 2 Year 2016 and Regulation of the Director General of Customs and Excise No. 3 Year 2016. The differences among Tempat Penimbunan Sementara (TPS) or Temporary Storage, Gudang Berikat (GB) or Bonded Warehouse compared to Pusat Logistik Berikat (PLB) or Bonded Logistics Center as the new competitive advantage as new Customs Facility of Indonesia for reducing Logistics cost and time.

Keywords: temporary warehouse, bonded warehouse, bonded logistics center, customs facility
\end{abstract}

\section{Introduction}

Bonded Logistics Center or Pusat Logistik Berikat (PLB) is a customs facility that is expected to be a new breakthrough to reduce the time and cost of logistics in Indonesia. The use of PLB has been done in other countries, as has been done in China. In Tianjin area has been built a Bonded Logistics Center or PLB located in the Northwest of Tianjin Economic Development with an area of 900.000 square meters with plans for a warehouse area of 220,000 square meters. (Peterson, 2016). The use of PLB as a raw material storage warehouse that is also applicable such as Distribution Center (DC) is an advantage to facilitate the distribution process. (Baddeley \& Kopelman, 2011) This is because the current pattern of goods distribution in Indonesia is still using the concept of point to point compared with the model hub and spoke. 

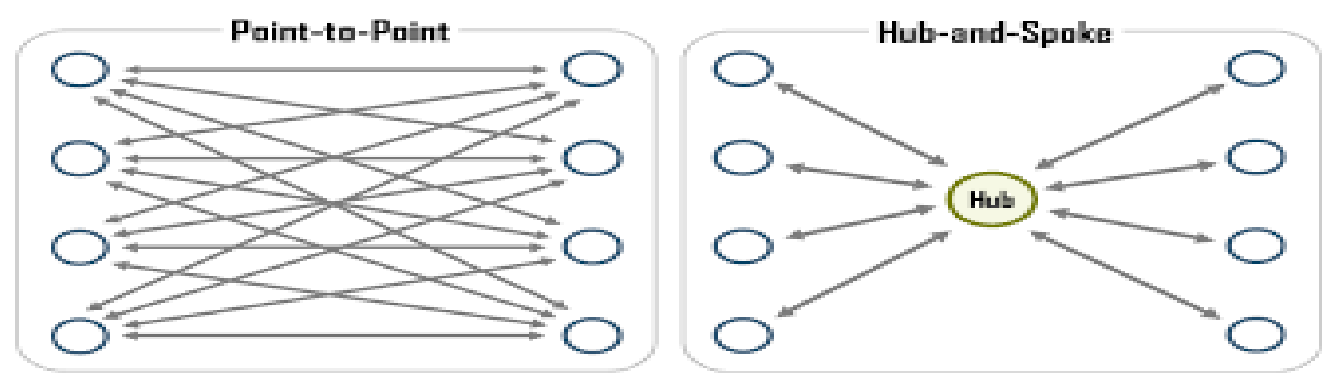

Figure 1

The Difference Between PTP and HAS

Based on the Regulation of the Director General of Customs and Excise Republic of Indonesia No.Per-01/BC/2016 concerning the Management of Bonded Logistics Center, hereinafter abbreviated as PLB is TPB (Bonded Stockpiling) hereinafter abbreviated as TPB is a building, place or area meeting certain requirements used) to stock goods originating outside customs areas and/or goods originating from elsewhere in customs areas, may be accompanied by 1 (one) or more simple activities within a certain period of time to be reissued. (B. dan C. Direktur Jenderal, 2016a)

PLB is an area or a place used to store goods of foreign origin or domestic origin with the income given customs facilities, taxation, and other facilities. PLB is analogous to such a warehouse abroad so that goods shipped from abroad to PLB are not subject to import duties or import taxes. Likewise with the fulfillment of import restriction provisions, not yet applied when the import of goods to the PLB except for certain goods. Domestic goods to be exported, can be entered into PLB and can be completed fulfillment of export regulations such as payment of export duty and fulfillment of export restriction provisions. (B. dan C. Direktur Jenderal, 2016a)

Starting from identifying the national logistic problem related to PLB is by way of public hearings and discussion with the association as well as formulating the construction of problems which then PLB became one of the mandate of the package of economic policy volume II issued by the Government of Indonesia on 29 September 2015 to answer the high challenge 
national logistics costs that make the domestic industry less competitive. Then on November 25, 2015 issued Government Regulation No. 85 of 2015 on legal basis PLB followed by the issuance of Regulation of the Minister of Finance Republic of Indonesia No. 272/PMK.04/2015 on PLB as The Ministry of Trade of Republic of Indonesia also issued Regulation of the Minister of Trade No.64/M-DAG/PER/9/2016 on the Provisions on the Importation of Outsourcing of Customs Area and Outsourcing from Bonded Logistics Logistics Centers.

Development of applications related to PLB and its development is done for example by the application of customs notification document service (BC 1.6 for goods import into PLB and BC 2.8 for removing goods from PLB to production site) in accordance with Perdirjen BC Number PER-02/BC/2016 related BC 1.6 and Perdirjen BC No. PER-03/BC/2016 relating to BC 2.8, as well as the application of appropriate facility recommendation (Go-fast). D. C. Direktur Jenderal, 2016) (B. dan C. Direktur Jenderal, 2016b). In a period of less than 2 months the Bonded Logistics Center was inaugurated on March 10, 2016 at 10.00 am by the President of the Republic of Indonesia Mr. Joko Widodo in the warehouse of PT. Cipta Krida Bahari Cakung, Jakarta. (Supriatin, 2016).

In Phase I, 11 logistics companies have been inaugurated as PLB in the first stage with various business fields: stockpiling to support mining industry, oil and gas industry, cosmetic industry, food and beverage industry, automotive industry, textile industry, petrochemical industry, and small industry and medium. In phase II until the end of October 2016, there are 28 PLBs that have been inaugurated and predicted to continue to grow considering the enormous interest of business actors towards this policy. In Phase III, it is targeted that in 2017, more than 20 PLB will be inaugurated with additional commodities in the field of weapons, fisheries and food in Bitung and Makassar. Within 1 year 
journey since inaugurated by President Joko Widodo, there are already about 34 PLB spread in Indonesia. (Afrianto, 2017)

PLB's goal is to make Indonesia a national/international Logistics distribution center to support the distribution of cheap and efficient logistics and support the growth of domestic industry. PLB as an alternative to national Logistics solutions in order to provide a logistics center to meet the needs of targeted industries, provide access to raw materials for import and export access to SMEs, and become a logistics hub in Asia Pacific by 2018.

\section{Method}

The research is qualitative to describe in depth how PLB is different from TPS and GB. This research was conducted in two places namely PT. Agility and Association of Indonesia Bonded Logistics Center (PPLBI). Sources of data or research subjects in this study are informants who have the capability and competence so that the information provided credible and in accordance with the needs of this study (purposive). Because of this research the main objective is to know how PLB can reduce the time and cost of logistics, it is necessary informants who not only have academic expertise in distribution management, but also practitioners who are everyday and involved in the scope of PLB.

The data analysis techniques used in this study use an approach developed by Miles and Huberman that include (after data collection) data reduction, data separation from unfocused, too detailed and others so that the data will reveal patterns or themes. Next is to display data (data display) that serves to help understand for advanced analysis of an information or event. The last process is the conclusion of the researchers based on the pattern and theme. Withdrawal conclusion is done continuously, that is while done at the time of data reduction and data display done.(Miles, Huberman, \& Saldana, 2014) 


\section{Result And Discussion}

A. The privileges or benefits of PLB include:

1. Profit and cash flow or flexibility in taxation and customs ie goods imported from abroad to PLB is not subject to import duties on import duties. Import duties and import taxes are paid by importers when removing goods from PLB domestically for import to be used. On the expenditure of goods from the PLB to importers in the country shall not be subject to domestic VAT.

2. Flexibility of importation of goods that are imported into PLB can be from overseas, domestic, free area, and other special area). Profit and cash flow or flexibility in taxation and customs ie goods imported from abroad to PLB have not been collected import duty import tax. Import duties and import taxes are paid by importers when removing goods from PLB domestically for import to be used. On the expenditure of goods from the PLB to importers in the country shall not be subject to domestic VAT.

3. The flexibility of the storage period in the PLB can be landfill activities for up to 3 years and can be extended to a maximum of 3 years if the goods covered are goods for oil and/or gas operational purposes, mining, certain industries, other industries with the permission of Head Office Customs.

4. Flexibility of activities within the PLB, in addition to carrying out stockpiling, the PLB is also allowed to perform simple work such as packaging, cutting, and other simple activities as long as it is not a manufacturing activity.

5. Flexibility of goods ownership, goods that are dumped in PLB should not be owned by PLB entrepreneurs but may also goods owned by overseas suppliers (consignment), goods deposited from the owner of goods in the country or the owner of goods abroad (deposit).

6. The flexibility of the restriction provisions is not enforced upon entry. 
Flexibility of origin and destination of goods (one to many, many to one, many to many).

a. Period of lifetime license until revoked.

b. Using the customs value at clearance.

c. Speed of service including IT based service so that paperless, priority clearance, document periodical expenditure.

d. Temporary import settlement is the completion of the lease of operational cost of oil and gas production (cost recovery).

e. Certified of Origin (COO) facility is accepted and allowed partial expenditure.

f. Survey by surveyor can be implemented in PLB.

Here is the difference between Temporary Storage (TPS), Bonded Warehouse (GB) and PLB as below:

Table 1

Differences of Temporary Shelter, Bonded Warehouse, and Bonded Logistics Center

\begin{tabular}{|c|c|c|c|c|}
\hline No. & Concept & TPS & GB & PLB \\
\hline 1. & Definition & $\begin{array}{l}\text { TPS is a building } \\
\text { and/ or field or } \\
\text { other place that is } \\
\text { likened to it in the } \\
\text { Customs Area to } \\
\text { stockpile while } \\
\text { awaiting loading } \\
\text { or disbursement }\end{array}$ & $\begin{array}{l}\text { GB for stockpiling of } \\
\text { imported goods, may } \\
\text { be accompanied by } 1 \\
\text { (one) or more } \\
\text { activities in the form } \\
\text { of packing/packing, } \\
\text { sorting, kitting, } \\
\text { packing, setting, } \\
\text { cutting, on certain } \\
\text { items within a } \\
\text { specified time period } \\
\text { to be reissued }\end{array}$ & $\begin{array}{l}\text { TPB for stock } \\
\text { goods originating } \\
\text { outside customs } \\
\text { areas and/or goods } \\
\text { originating from } \\
\text { elsewhere in } \\
\text { customs areas, } \\
\text { may be } \\
\text { accompanied by } 1 \\
\text { (one) or more } \\
\text { simple activities } \\
\text { within a specified } \\
\text { period for reissue }\end{array}$ \\
\hline 2. & Goods Ownership & Free & Private & $\begin{array}{l}\text { Private, } \\
\text { Consignment }\end{array}$ \\
\hline 3. & Storage Time & 30 days & 1 year & 3 years ++ \\
\hline 4. & Activity & Storage & $\begin{array}{l}\text { Storage and simple } \\
\text { activities }\end{array}$ & $\begin{array}{l}\text { Storage and } \\
\text { simple activities } \\
++\end{array}$ \\
\hline 5. & Customs Value & $\begin{array}{l}\text { Used when } \\
\text { clearance out }\end{array}$ & $\begin{array}{l}\text { Used when clearance } \\
\text { in }\end{array}$ & $\begin{array}{l}\text { Used when } \\
\text { clearance in }\end{array}$ \\
\hline
\end{tabular}


Table 1, Cont. Differences of Temporary Shelter, Bonded Warehouse, and Bonded Logistics Center

\begin{tabular}{|c|c|c|c|c|}
\hline 6. & $\begin{array}{l}\text { Goods Origin \& } \\
\text { Destination }\end{array}$ & $\begin{array}{l}\text { Origin: Domestic } \\
\text { and Overseas (for } \\
\text { Export) } \\
\text { Destination: } \\
\text { Flexible }\end{array}$ & $\begin{array}{l}\text { Origin: Overseas } \\
\text { Destination: } \\
\text { Flexible } \\
\text { "One to One" }\end{array}$ & $\begin{array}{l}\text { Origin: } \\
\text { Flexible } \\
\text { Destination: } \\
\text { "One to many, } \\
\text { many to one } \\
\text { many to many" }\end{array}$ \\
\hline 7. & Restricted Terms & $\begin{array}{l}\text { Not yet applied } \\
\text { when clearance in }\end{array}$ & $\begin{array}{l}\text { Not yet applied when } \\
\text { clearance in }\end{array}$ & $\begin{array}{l}\text { Not yet applied } \\
\text { when clearance in }\end{array}$ \\
\hline 8. & Partial Shipment & $\begin{array}{l}\text { Accepted and } 1 \\
\text { time clearance }\end{array}$ & $\begin{array}{l}\text { Accepted and } 1 \text { time } \\
\text { clearance }\end{array}$ & $\begin{array}{l}\text { Accepted \& can } \\
\text { partial }\end{array}$ \\
\hline 9. & Master list Facility & - & - & $\begin{array}{l}\text { Cost Recovery for } \\
\text { Oil \& Gas }\end{array}$ \\
\hline 10. & $\begin{array}{c}\text { Fiscal Expenditure } \\
\text { At Clearance }\end{array}$ & $\begin{array}{l}\text { Customs Duty \& } \\
\text { Import Tax }\end{array}$ & $\begin{array}{l}\text { Customs Duty, } \\
\text { Import Tax \& VAT }\end{array}$ & $\begin{array}{l}\text { Customs Duty \& } \\
\text { Import Tax }\end{array}$ \\
\hline 11. & $\begin{array}{l}\text { Permission Time } \\
\text { Period }\end{array}$ & 5 years & $\begin{array}{l}\text { Organizer }<5 \text { years } \\
\text { Employers }<3 \text { years }\end{array}$ & $\begin{array}{l}\text { Lifetime until } \\
\text { revoked }\end{array}$ \\
\hline 12. & $\begin{array}{l}\text { One permission for } \\
\text { multiple locations }\end{array}$ & - & - & $\begin{array}{l}\text { Owned by the } \\
\text { same legal entity }\end{array}$ \\
\hline 13. & $\begin{array}{l}\text { Decision Letter } \\
\text { Format }\end{array}$ & Standard & Standard & $\begin{array}{l}\text { Customized, } \\
\text { Thematic, KPI }\end{array}$ \\
\hline 14. & $\begin{array}{l}\text { Customs Duty } \\
\text { Payment }\end{array}$ & $\begin{array}{l}\text { Immediately } \\
\text { enforced }\end{array}$ & Immediately enforced & $\begin{array}{l}\text { Periodic } \\
\text { documents and } \\
\text { Payments are on } \\
\text { hold }\end{array}$ \\
\hline
\end{tabular}

Source: Directorate General of Customs and Excise Republic of Indonesia

Within 1 year since it was inaugurated, the achievements made by PLB are to open 30 entities of Bonded Logistics Centers in Indonesia spread across the province as follows: Jakarta, West Java, East Java, Bali, East Kalimantan and Aceh. 

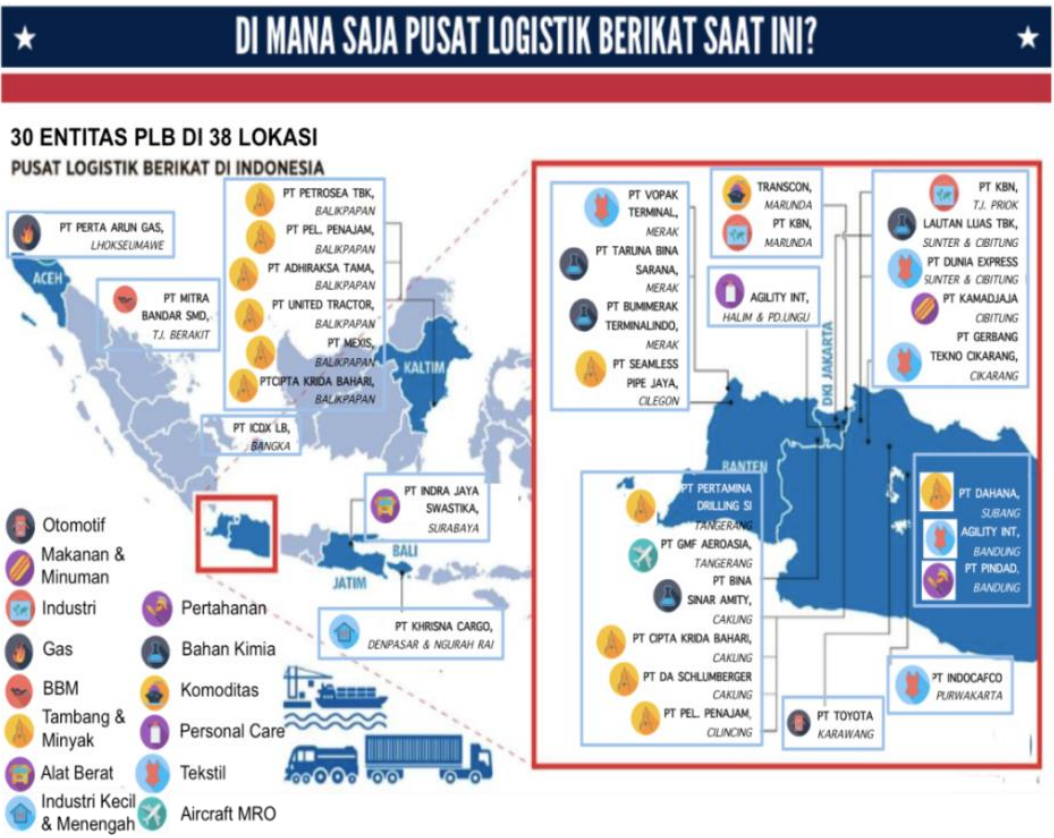

Source: Directorate General of Customs and Excise Republic of Indonesia

(Direktorat Jendral, 2017)

Figure 2

\section{$P L B$ Entities in Indonesia}

While the achievements are successfully performed by PLB is as follows:

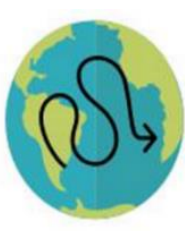

\section{Rp 1.16 TRILIUN}

Nilai Inventory yang disimpan di PLB

Sebelum adanya PLB, barang-barang ini disimpan di gudang-gudang dan pusat logistik di luar Indonesia, padahal tujuan akhirnya ke dalam Indonesia sendiri.

Source: Directorate General of Customs and Excise Republic of Indonesia (Direktorat Jendral, 2017)

Figure 3

PLB Achievements Indonesia

\section{follows:}




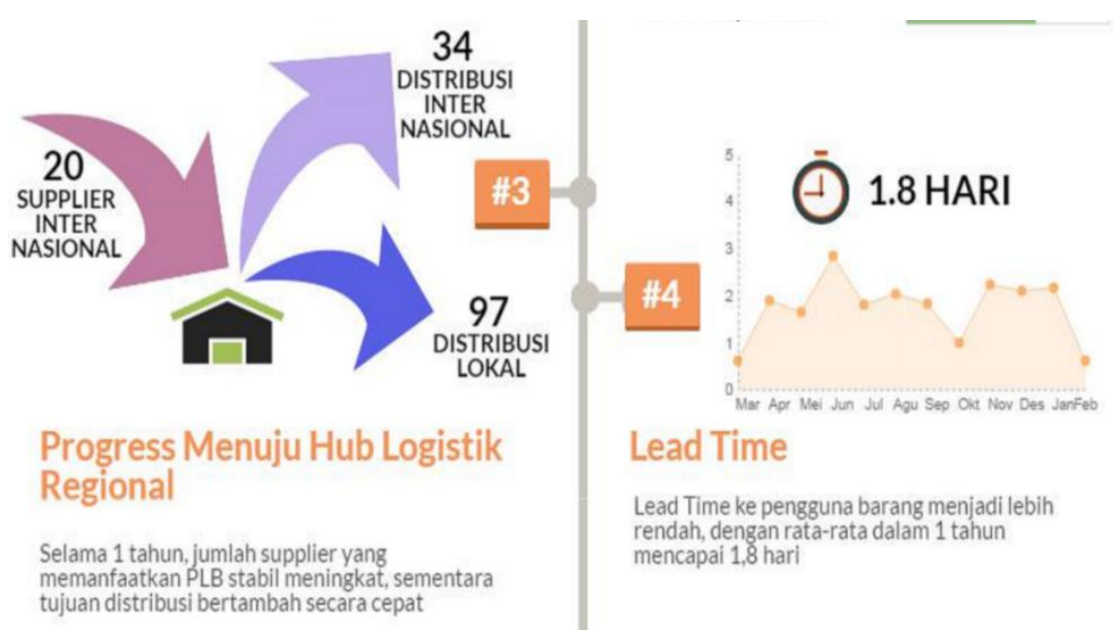

Source: Directorate General of Customs and Excise Republic

Figure 4

$P L B$ Achievements in Indonesia

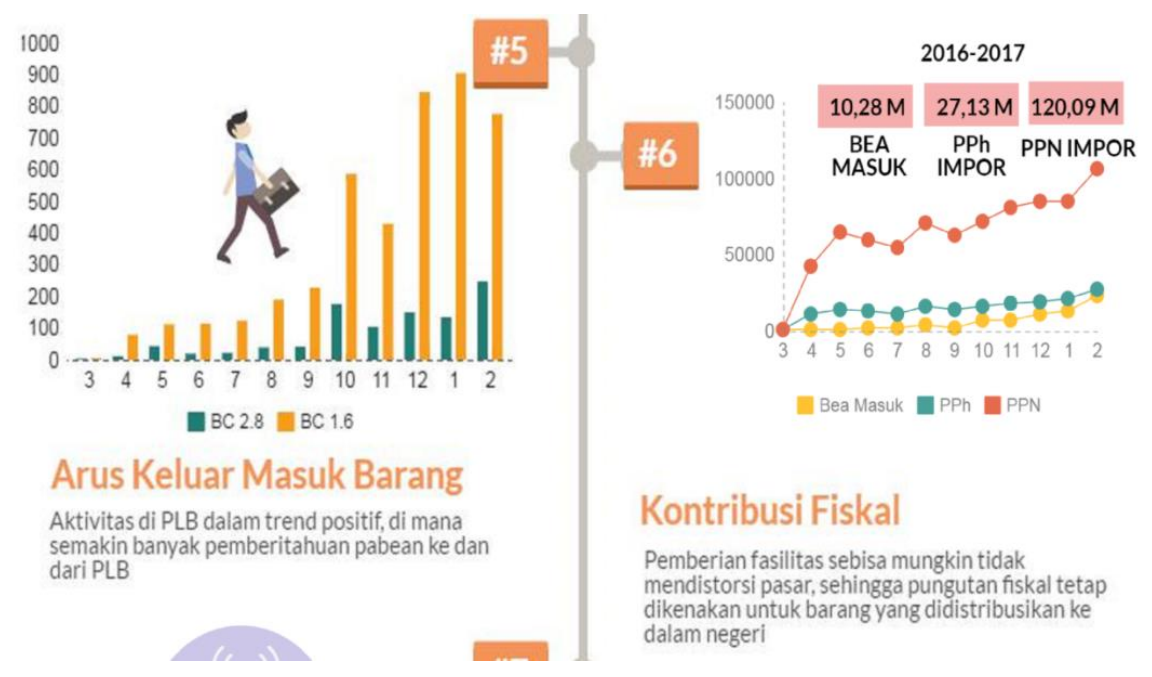

Source: Directorate General of Customs and Excise Republic of Indonesia

(Direktorat Jendral, 2017)

Figure 5

PLB Achievements in Indonesia 


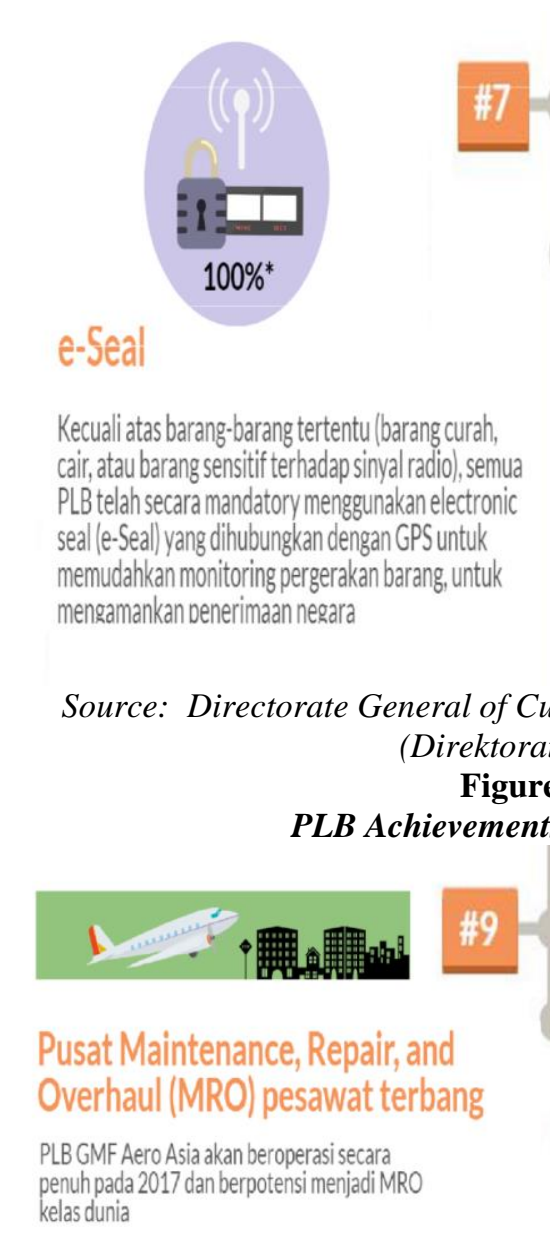

dikenakan untuk barang yang didistribusikan ke dalam negeri

\#8

Penelusuran Surveyor di dalam PLB

PLB Petrosea dan PLB CKB telah efektif melakukan penelusuran teknis di dalam PLB, di mana sebelumnya penelusuran teknis dilakukan di negara muat

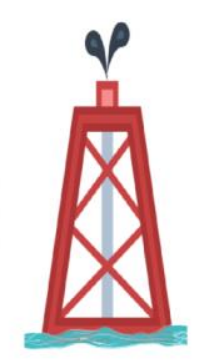

Direktorat Jendral, 2017)

Figure 6

$P L B$ Achievements in Indonesia

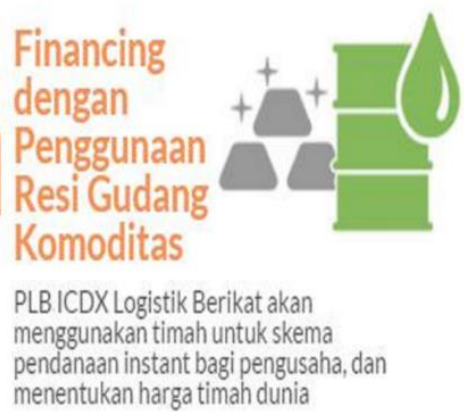

Source: Directorate General of Customs and Excise Republic of Indonesia (Direktorat Jendral, 2017)

Figure 7

PLB Achievements in Indonesia

\section{Conclusion}

The fundamental difference between PLB and TPS and GB is that it can repay the outgoing goods and does not have to pay all import duty and other taxes upfront so as to make the company's cash flow to be good besides it can be dumped for 3 (three) years. With the PLB, the manufacturing company does not need imports and does not need to take goods from abroad because it is enough to take from the bonded warehouse. The presence of PLB makes 
business activities more efficient. Because, later the manufacturing company no longer need to import raw materials, capital goods and materials helper from abroad. Logistic Management, according to KEPRES 44/45 Year 1974, is identical with the supply management. (Raden Didiet Rachmat Simarmata \& Len Togas, 2015). Dwelling time improvement to control industry's supply and demand is one of the key factors for national economic changing that PLB should give solution. (Rafi, n.d.) However, PLB is able to store Finished Goods instead of Raw Material, most probably there will be a "business shock" especially for retail industry. Big retail players will take this as an facility as their competitive advantage in the industry. (Republic of Indonesia, 2017)

PLB is expected to integrate multiple sectors that are part of supply chain management that has a role to include acceptance, storage, maintenance, distribution and destruction as well as reporting logistics and disaster management equipment for quality and quantity to be guaranteed. Therefore need special skill to handle. If not, can cause mismanagement and high economy cost. (Lesmini, Purwanto, \& Trisakti, 1969) (Edi, n.d.)

PLB is expected to move the function of raw material warehouse from abroad such as Malaysia to Indonesia. With PLB as a first step to facilitate the process of logistics in Indonesia to bring the big dreams closer. Literally, PLB can be considered as Blue Ocean Strategy is an effort to create a market niche through a continuous innovation with the main key: see the consumer's needs that has not been adapted by the competitors so that a proitable business opportunity is opened widely. (STMT Trisakti, Setyawati, Dian Octaviani STMT Trisakti, \& Dian Octaviani, 2015). In addition, the PLB is considered to provide benefits for the industry in the country with reduced logistics costs and for the future become the National Logistics Hub and Asia Pacific. (Admin Web Bea \& Cukai, 2016) 


\section{References}

Admin Web Bea \& Cukai. (2016). Jadikan Indonesia Hub Logistik Asia Pasifik. Retrieved from http://www.beacukai.go.id/berita/jadikanindonesia-hub-logistik-asia-pasifik.html

Afrianto, D. (2017). 34 Perusahaan Garap Logistik Berikat, Menkeu: Saya Tidak Mudah Puas. Retrieved from https://economy.okezone.com/read/2017/04/12/320/1665663/34perusahaan-garap-logistik-berikat-menkeu-saya-tidak-mudah-puas

Baddeley, A., \& Kopelman, M. D. (2011). The Handbook of Logistics and Distribution Management. Cognition (Vol. 25). https://doi.org/10.3109/02699206.2011.557176

Direktorat Jendral, B. dan C. (2017). Satu Tahun Pusat Logistik Berikat.

Direktur Jenderal, B. D. C. PER-02/BC/2016 tentang Tata Laksana Pengeluaran Barang Impor Dari Kawasan Pabean Untuk Ditimbun Di Pusat Logistik Berikat, $2016 \S$ (2016). Jakarta.

Direktur Jenderal, B. dan C. PER-01/BC/2016 tentang Tata Laksana Pusat Logistik Berikat (2016). Jakarta. Retrieved from www.beacukai.go.id

Direktur Jenderal, B. dan C. PER-03/BC/2016 tentang Tata Laksana Pengeluaran Barang Impor Dari Pusat Logistik Berikat Untuk Dimpor Untuk Dipakai, 2015 § (2016). Retrieved from www.beacukai.go.id

Edi, D. W. (n.d.). Biaya Logistik Dan Kelancaran Pengiriman Logistic Costs and the Good' S Delivery, 3(2), 227-243.

Lesmini, L., Purwanto, B., \& Trisakti, S. (1969). Ekonomi Maritim \& Sumber Daya Manusia Indonesia, 372-389.

Miles, M. B., Huberman, M. a, \& Saldana, J. (2014). Drawing and Verying Conclusions. Qualitative Data Analysis: A Methods Sourcebook, 275-322. https://doi.org/January 11, 2016

Peterson, A. (2016). Report Information from ProQuest. Washington Post, (May). https://doi.org/http://dx.doi.org/10.1108/17506200710779521

Raden Didiet Rachmat Simarmata, J. H., \& Len Togas, N. (2015). Study on The Cause of Stock Out of Logistic Installation in Harapan Kita Hospital. Jurnal Manajemen Transportasi \& Logistik, 2(1), 79-92.

Rafi, S. (n.d.). Dwelling time management, 220-228.

Republic of Indonesia, M. of T. (2017). Laporan Akhir Kajian Evaluasi Manfaat Pusat Logistik Berikat Dalam Mendukung Daya Saing Industri Nasional.

STMT Trisakti, H., Setyawati, A., Dian Octaviani STMT Trisakti, R., \& Dian Octaviani, R. (2015). The Implementation of Blue Ocean Strategy To Create A Market Niche. Jurnal Manajemen Transportasi \& Logistik, 2(2), 191-198.

Supriatin. (2016). Resmikan PLB, Jokowi yakin Indonesia dapat bersaing di luar negeri. Retrieved from https://www.merdeka.com/peristiwa/resmikanplb-jokowi-yakin-indonesia-dapat-bersaing-di-luar-negeri.html 